\title{
Renal function after laparoscopic cholecystectomy and analgesia with tramadol and dipyrone or ketorolac
}

\author{
Tiago Pechutti Medeiros ${ }^{1}$, Pedro Thadeu Galvão Vianna ${ }^{2}$, Leopoldo Muniz da Silva ${ }^{3}$, \\ Lídia Raquel de Carvalho ${ }^{4}$, Gilberto Elias Wady ${ }^{5}$, Leandro Gobbo Braz², \\ Yara Marcondes Machado Castiglia ${ }^{2^{\star}}$ \\ ${ }^{1}$ Graduate Program in Anesthesiology, Botucatu Medical School, UNESP-Universidade Estadual Paulista, Botucatu, Brazil \\ ${ }^{2}$ Department of Anesthesiology, Botucatu Medical School, UNESP-Universidade Estadual Paulista, Botucatu, Brazil; \\ *Corresponding Author: yarac@,fmb.unesp.br \\ ${ }^{3}$ São Luiz Hospital, São Paulo, Brazil \\ ${ }^{4}$ Department of Biostatics, Institute of Biosciences, UNESP-Universidade Estadual Paulista, Botucatu, Brazil \\ ${ }^{5}$ Mercy Hospital, São Carlos, Brazil
}

Received 4 September 2013; revised 12 October 2013; accepted 28 October 2013

Copyright (C) 2013 Tiago Pechutti Medeiros et al. This is an open access article distributed under the Creative Commons Attribution License, which permits unrestricted use, distribution, and reproduction in any medium, provided the original work is properly cited.

\begin{abstract}
Background: Laparoscopic cholecystectomy (LC) reduces surgical trauma and hospital stay, but requires effective and safe postoperative analgesia. This prospective and double-blind study investigated the effects of analgesia with tramadol combined with either dipyrone or ketorolac on the postoperative renal function of patients submitted to LC. Methods: Pre- and postoperatively (PO), estimated glomerular filtration rates (GFR), obtained by two formulas dependent on blood $\mathrm{Cr}$ and one on blood cystatin $\mathrm{C}$ values, and tubular enzymuria-alkaline phosphatase (AP), Y-glutamiltransferase ( $Y$-GT)were determined in well hydrated patients who underwent $L C$ and analgesia with tramadol combined with either dipyrone (Dipyrone, $n=63$ ) or ketorolac (Ketorolac, $n=63$ ). Upon discharge from the post-anesthetic care unit (PACU), pain (through Verbal Numerical Scale-VNS) and need for rescue analgesia with morphine were evaluated. Results: There was hemodilution PO, which made GFR profile analysis more difficult-those dependent on $\mathrm{Cr}$ increased and statistically correlated, but those dependent on cystatin $\mathrm{C}$ did not change. There was a significant PO increase in AP in the Dipyrone and Ketorolac groups, and in the product of the both enzymes in the Ketorolac group. Upon PACU discharge, the Dipyrone group showed signifi-
\end{abstract}

cantly higher VNS scores than the Ketorolac group. All patients received morphine PO, and the total dose needed for pain control differed between groups, but without statistical significance. Conclusions: The association of tramadol with dipyrone or ketorolac in well hydrated patients submitted to LC had similar analgesic effectiveness in the PACU. Postoperatively, the effect on GFR may have been masked by hemodilution, and enzymuria was discreetly enhanced when ketorolac was used.

Keywords: Kidney Function Tests;

Pneumoperitoneum; Biological Markers; Cystatin C; Ketorolac; Analgesia

\section{INTRODUCTION}

Renal venous pressure, hydrostatic pressure and glomerular filtration rate (GFR) are adversely affected by pneumoperitoneum. However, expansion of the extracellular volume can be beneficial to renal function [1-3]. Pain after laparoscopic surgery is multifactorial and may be quite intense. Current pain management relies on a number of strategies, including the concomitant use of opioids and anti-inflammatory drugs [4].

Remifentanil, a synthetic opioid used in anesthesia, has a predictable duration of action (elimination half-life of $8-20$ minutes) because it is metabolized via plasma esterases [5]. While reducing opioid-induced adverse ef- 
fects, remifentanil does not provide residual analgesia at the immediate postoperative period. Tramadol is a centrally acting analgesic that consists of two enantiomers, both of which contribute to analgesic activity via different mechanisms: (+)-tramadol and the metabolite $(+)$-0-desmethyl-tramadol are agonists of $\mu$ opioid receptor. (+)-tramadol inhibits serotonin re-uptake, and (-)-tramadol inhibits norepinephrine re-uptake, increasing the inhibitory effects on pain transmission in the spinal cord [6]. It is excreted via the kidney (over 30\%), and in bolus doses and various injections it does not affect renal blood flow in normal rats [7]. Tramadol and nonsteroidal anti-inflammatory drugs (NSAID) have often been combined for the clinical treatment of post-operative pain. However, the stimulation of opioid receptors may increase pain sensitivity immediately after opioid administration (opioid-induced hyperalgesia). Therefore, investigating the effects of combining opioids with nonopioid analgesics, including NSAIDs, would be of especial interest for anesthesia researchers [8].

NSAIDs block the enzyme cyclooxygenase (COX) and, in consequence, the synthesis of renal vasodilator prostaglandins (PG) [9], which help maintain renal blood flow and GFR, modulating the vasoconstrictor effects of angiotensine II or norepinephrine [10]. However, in rats anesthetized with sodium pentobarbital, the NSAID ketoprofen, administered early after hypotension due to hemorrhage, caused fewer changes in renal function and hystology than the barbituric [11].

Serum cystatin C level, an early marker of mild GFR deterioration [12], is a useful endogenous alternative to estimate GFR. However, in a study including 8058 individuals aged $25-75$ years, besides not being superior to creatinine in measuring GFR, serum cystation $\mathrm{C}$ seemed to be influenced by factors other than kidney function alone [13]. To measure the integrity of tubular cells, assessing urinary concentrations of renal enzymes is a sensitive non-invasive method. These renal enzymes are located on specific sites of the kidney: $\gamma$-glutamyltransferase $(\gamma$-GT) is mainly found in the tubules near the loop of Henle, while alkaline phosphatase (AP) is found in the epithelial cells of the proximal tubule [14]. As such, once serum creatinine, cystatin $\mathrm{C}$ and urinary enzymes are determined, results that would possibly quantify perioperative injury to the kidneys may be obtained.

Thus, the aim of this clinical prospective trial was to assess the effects of two analgesia regimens on postoperative renal function in patients submitted to general anesthesia for laparoscopic cholecystectomy.

\section{METHODS}

This was a randomized, placebo-controlled, doubleblind trial. After Institutional Review Board approval, written informed consent was obtained from a total of 126 patients scheduled for general anesthesia for elective laparoscopic cholecystectomy with $\mathrm{CO}_{2}$ pneumoperitoneum at $13 \mathrm{mmHg}$ for chronic cholecystitis due to cholelithiasis. Patients older than 60 years, allergic to NSAIDs or opioids, with an ASA physical status of more than III, plasma creatinine higher than $1.5 \mathrm{mg} / \mathrm{dl}$ or heart failure, and users of nephrotoxic drugs were excluded. Oral $15 \mathrm{mg}$ midazolam was given as pre-medication to all patients, one hour before anesthesia. Patients were included in one of two groups: Dipyrone group-received placebo (saline) intravenously (iv) at the time of pre-medication, and $100 \mathrm{mg}$ tramadol with $2 \mathrm{~g}$ dipyrone, iv, approximately $30 \mathrm{~min}$ before the end of anesthesia for analgesia; Ketorolac group-received $30 \mathrm{mg}$ ketorolac, iv, at the time of pre-medication, and $100 \mathrm{mg}$ tramadol with $30 \mathrm{mg}$ ketorolac, iv, approximately $30 \mathrm{~min}$ before the end of anesthesia for analgesia. The placebo and ketorolac solutions were administered by a nurse, who prepared them in an identical volume $(10 \mathrm{ml})$. The same nurse prepared the drugs for postoperative analgesia, so that the double-blind condition of the study was maintained.

In the operating theater, all patients were monitored with electrocardioscopy, pulse oxymeter and non-invasive arterial pressure measurement. All patients were given $10 \mathrm{ml} / \mathrm{kg} / \mathrm{h}$ Ringer lactate solution. At this time point (T1), $20 \mathrm{ml}$ of blood were collected for the laboratory assessment of cystatin $\mathrm{C}$, by the immunonephelometric method using Dade Behring ${ }^{\circledR}$ reagents and calibrators (N Latex Cystatin C, Dade Behring, Deerfield, USA), urea and creatinine (dry-chemical method), and albumin by protein electrophoresis. Additionally, $80 \mathrm{ml}$ of urine (after bladder catheterization) were collected to dose AP, $\gamma$-GT, and creatinine, by the Vitros 950Johnson \& Johnson ${ }^{\circledR}$ (USA) automation system. Urinary creatinine concentrations in $\mathrm{mg} / \mathrm{dl}$ were multiplied by 0.0884 for conversion to $\mathrm{mmol} / \mathrm{l}$, and used to eliminate the effect of urinary dilution: $\mathrm{AP} / \mathrm{creatinine}(\mathrm{U} / \mathrm{mmol})$; $\gamma$-GT/creatinine (U/mmol); AP $\times \gamma$-GT/creatinine $(\mathrm{U} / \mathrm{mmol})$. Twenty four hours after the end of anesthesia and surgery (time point T2), $20 \mathrm{ml}$ of blood and $80 \mathrm{ml}$ of urine were once more collected, and the same laboratory assays were repeated.

\subsection{Anesthesia Procedures}

Anesthesia was induced with intravenous $0.5 \mu \mathrm{g} / \mathrm{kg} / \mathrm{min}$ remifentanil, $2 \mathrm{mg} / \mathrm{kg}$ propofol, and $0.6 \mathrm{mg} / \mathrm{kg}$ rocuronium. After tracheal intubation to perform general anesthesia, intermittent positive pressure ventilation was continued, and end-tidal carbon dioxide pressure was monitored to remain around $33 \mathrm{mmHg}$. Anesthesia was maintained with $0.25 \mu \mathrm{g} / \mathrm{kg} / \mathrm{min}$ remifentanil, sevoflurane adjusted according to hemodynamic parameters, 4 
liters of fresh gas comprising $\mathrm{N}_{2} \mathrm{O}$ in $50 \%$ of $\mathrm{O}_{2}$, controlled breathing and rebreathing with a semiclosed system.

Analgesia in patients from both the Dipyrone and the Ketorolac groups was assessed by the Verbal Numerical Scale (VNS) at admission to the post-anesthesia care unit (PACU), and at every 15 minutes until discharge, at least two hours after admission to the PACU. According to instructions received before anesthesia and surgery, patients rated pain on a zero-ten scale where: zero = absence of pain, one $(1)=$ minimum existing pain, and $10=$ the worst pain imaginable. In the PACU, when values were above three in the VNS, $1 \mathrm{mg}$ morphine hydrochloride was administered, iv, every 10 minutes until pain cessation or $\mathrm{VNS}=3$. Level of sedation (awake and cooperative, asleep and cooperative after stimulus, asleep and uncooperative) and quantity of morphine used were also assessed in the PACU.

GFR was estimated by the following formulas: GFRLarsson $(\mathrm{ml} / \mathrm{min})[15,16]=77.24 \times\left[\right.$ cystatin $\mathrm{C}^{-1.2623}$ (mg/l)]; GFR-MDRD ("Modification of Diet in Renal Disease") $\left(\mathrm{ml} / \mathrm{min} / 1.73 \mathrm{~m}^{2}\right)[17]=170 \times(\text { creatinine })^{-0.999}$ $\times(\text { age })^{-0.176} \times[0.762$ if female $] \times[1.18$ if black $] \times$ (urea $^{-0.17} \times(\text { albumin })^{0.318}$ and GFR-CG (ml/min) [18] = $(140-$ age $) \times$ weight $/$ serum creatinine $\times 72 \times[0.85$ if female].

\subsection{Statistical Analysis}

The exact Fisher test was used to study the association between group and gender. The Student t test was used for comparisons between groups regarding age, pre- and postoperative cystatin $\mathrm{C}$ level ( $\Delta$ cystatin $\mathrm{C}$ ), and the amount of morphine used in the PACU. Profile analysis was used to study the effect of group, time and time $\times$ group interactions. Correlations between variables were analyzed by Pearson's correlation coefficient. Statistical significance was set at $p<0.05$.

\section{RESULTS}

Duration of anesthesia was $70 \mathrm{~min} \pm 10$ in the Dipyrone group, and $68 \mathrm{~min} \pm 13$ in the Ketorolac group $(p=0.42)$. Age was 40.9 years \pm 12.1 in the Dipyrone group, and 40.2 years \pm 11.5 in the Ketorolac group ( $p=$ 0.75). In the Dipyrone and Ketorolac groups, females represented $73 \%(46)$ and $82.5 \%$ (52) of the patients, respectively $(p=0.28)$. Weight was $71.5 \mathrm{~kg} \pm 13.5$ in the Dipyrone group, and $73.6 \mathrm{~kg} \pm 14.9$ in the Ketorolac group ( $p=0.31)$. It can be said that the groups were homogeneous (Table 1).

Cystatin $\mathrm{C}$ values did not differ between groups ( $p=$ $0.30)$, and time points $(p=0.09)$, and there was no time points $\mathrm{x}$ groups interaction $(p=0.44)$ (Table 1). Serum creatinine values were not different between groups $(p=$
$0.62)$, nor was there time points $\times$ groups interaction $(p=$ $0.10)$. However, there was a difference between time points ( $p=0.00001$ ) (Table 1). Plasma albumin presented the same profile with no difference between groups $(p=0.42)$, without time points $\times$ groups interaction $(p=0.27)$, but showing a difference between time points $(p=0.0005)$ (Table 1).

The GFR-Larsson was not different between groups ( $p$ $=0.33)$, and time points $(p=0.07)$, and there was no time points $\times$ groups interaction $(p=0.66)$ (Table 2). GFR-CG was not different between groups $(p=0.79)$, and did not exhibit time points $\times$ groups interaction $(p=$ 0.55 ). However, it was different between time points ( $p=$ 0.001) (Table 2). GFR-MDRD was not different between groups $(p=0.72)$, and did not exhibit time points $\times$ groups interaction $(p=0.58)$, but it differed between time points $(p=0.003)$ (Table 2$)$. A significant correlation was observed only between GFR-MDRD and GFR-CG values at T1 $(\mathrm{r}=0.48$ and $p=0.000)$ and T2 (r $=0.36$ and $p=0.000)$.

AP results significantly differed between groups ( $p=$ $0.02)$ and time points $(p=0.03)$, and showed time points $\times$ groups interaction $(p=0.001)$. Thus, Dipyrone group $>$ Ketorolac group and T1 $<$ T2 (Table 2). $\gamma$-GT presented a statistically significant difference between groups ( $p=$ $0.001)$, and time points $\times$ groups interaction $(p=$ $0.00002)$, with no difference between time points ( $p=$ $0.07)$. The product of the two enzymes significantly differed between groups $(p=0.005)$ and time points $(p=$ $0.008)$, and showed time points $\times$ groups interaction $(p=$ 0.0002) (Table 2).

Table 1. Clinical data of study group patients (Means \pm SD).

\begin{tabular}{|c|c|c|c|c|}
\hline Parameter & & $\begin{array}{l}\text { Dipyrone group } \\
\qquad(n=63)\end{array}$ & $\begin{array}{l}\text { Ketorolac group } \\
\qquad(n=63)\end{array}$ & $p$ \\
\hline Age (years) & & $40.9 \pm 12.1$ & $40.2 \pm 11.5$ & 0.75 \\
\hline Weight (kg) & & $71.5 \pm 13.5$ & $73.6 \pm 14.9$ & 0.31 \\
\hline Gender F:M & & $46: 17$ & $52: 11$ & 0.28 \\
\hline $\begin{array}{c}\text { Duration of } \\
\text { anesthesia (min) }\end{array}$ & & $70 \pm 10$ & $68 \pm 13$ & 0.42 \\
\hline \multirow{2}{*}{$\begin{array}{l}\text { Plasma cystatin } \\
\text { C }(\mathrm{mg} / \mathrm{l})\end{array}$} & $\mathrm{T} 1$ & $0.83 \pm 0.19$ & $0.78 \pm 0.18$ & ${ }^{*} 0.31$ \\
\hline & $\mathrm{T} 2$ & $0.84 \pm 0.18$ & $0.81 \pm 0.17$ & ${ }^{\#} 0.24$ \\
\hline \multirow{2}{*}{$\begin{array}{l}\text { Blood creatinine } \\
(\mathrm{mg} / \mathrm{dl})\end{array}$} & $\mathrm{T} 1$ & $0.78 \pm 0.14$ & $0.77 \pm 0.16$ & ${ }^{*} 0.62$ \\
\hline & $\mathrm{T} 2$ & $0.70 \pm 0.16$ & $0.73 \pm 0.19$ & ${ }^{\#} 0.00001$ \\
\hline \multirow{2}{*}{$\begin{array}{c}\text { Plasma } \\
\text { albumin (g/dl) }\end{array}$} & $\mathrm{T} 1$ & $4.1 \pm 0.7$ & $4.1 \pm 0.5$ & ${ }^{*} 0.42$ \\
\hline & $\mathrm{T} 2$ & $3.3 \pm 0.7$ & $3.7 \pm 2.5$ & ${ }^{\#} 0.0005$ \\
\hline $\begin{array}{l}\Delta \text { cystatin } \\
\mathrm{C}(\mathrm{mg} / \mathrm{ml})\end{array}$ & & $0.0017 \pm 0.14$ & $0.0030 \pm 0.15$ & ${ }^{*} 0.23$ \\
\hline
\end{tabular}

${ }^{*}=p$ between Dipyrone and Ketorolac groups; ${ }^{\#}=p$ between time point 1 (T1 - at the arriving in operating theater) and time point 2 (T2-24 h after the end of anesthesia and surgery). 
Table 2. Markers of renal function for the two groups on admission in the surgery theater (T1) and after 24 hours of anesthesia and surgery (T2) (Means $\pm \mathrm{SD}$ ).

\begin{tabular}{|c|c|c|c|c|}
\hline Parameter & & $\begin{array}{l}\text { Dipyrone } \\
\text { group } \\
(\mathbf{n}=63)\end{array}$ & $\begin{array}{c}\text { Ketorolac } \\
\text { group } \\
(\mathbf{n}=63)\end{array}$ & $p$ \\
\hline \multirow{2}{*}{ GFR-Larsson ( $\mathrm{ml} / \mathrm{min})$} & $\mathrm{T} 1$ & $61.5 \pm 19.4$ & $66.7 \pm 21.8$ & ${ }^{*} 0.33$ \\
\hline & $\mathrm{T} 2$ & $60.2 \pm 17.4$ & $61.6 \pm 17.0$ & ${ }^{\#} 0.07$ \\
\hline \multirow{2}{*}{ GFR-CG (ml/min) } & $\mathrm{T} 1$ & $114.6 \pm 29.5$ & $119.1 \pm 29.8$ & ${ }^{*} 0.79$ \\
\hline & $\mathrm{T} 2$ & $127.7 \pm 38.2$ & $126.1 \pm 32.7$ & ${ }^{\#} 0.001$ \\
\hline \multirow{2}{*}{$\begin{array}{l}\text { GFR-MDRD } \\
\left(\mathrm{ml} / \mathrm{min} / 1.73 \mathrm{~m}^{2}\right)\end{array}$} & $\mathrm{T} 1$ & $94.2 \pm 32.6$ & $93.7 \pm 26.5$ & ${ }^{*} 0.72$ \\
\hline & $\mathrm{T} 2$ & $105.5 \pm 42.8$ & $101.6 \pm 44.8$ & ${ }^{\#} 0.003$ \\
\hline \multirow{2}{*}{$\mathrm{AP} / \mathrm{U}_{\mathrm{Cr}}(\mathrm{U} / \mathrm{mmol})$} & $\mathrm{T} 1$ & $2.7 \pm 1.1$ & $2.0 \pm 0.3$ & ${ }^{*} 0.02$ \\
\hline & $\mathrm{T} 2$ & $3.5 \pm 1.6$ & $3.5 \pm 0.8$ & ${ }^{\#} 0.03$ \\
\hline \multirow{2}{*}{$\gamma-\mathrm{GT} / \mathrm{U}_{\mathrm{Cr}}(\mathrm{U} / \mathrm{mmol})$} & $\mathrm{T} 1$ & $4.1 \pm 2.0$ & $5.0 \pm 1.2$ & ${ }^{*} 0.001$ \\
\hline & $\mathrm{T} 2$ & $3.3 \pm 1.8$ & $5.5 \pm 2.5$ & ${ }^{\#} 0.07$ \\
\hline \multirow{2}{*}{$\begin{array}{c}\mathrm{AP} \times \gamma-\mathrm{GT} / \mathrm{U}_{\mathrm{Cr}} \\
(\mathrm{U} / \mathrm{mmol})\end{array}$} & $\mathrm{T} 1$ & $134.2 \pm 68.4$ & $86.3 \pm 22.0$ & ${ }^{*} 0.005$ \\
\hline & $\mathrm{T} 2$ & $85.1 \pm 45.8$ & $167.0 \pm 83.8$ & ${ }^{\#} 0.008$ \\
\hline
\end{tabular}

GFR $=$ glomerular filtration rate; $\mathrm{AP}=$ alkaline phosphatase; $\gamma$-GT $=$ $\gamma$-glutamiltransferase; $\mathrm{U}_{\mathrm{Cr}}=$ urinary creatinine; ${ }^{*}=p$ between Dipyrone and Ketorolac groups; ${ }^{*}=p$ between time points $\mathrm{T} 1$ and $\mathrm{T} 2$.

All patients were awake at PACU admission. VNS scores gradually decreased with time for all patients, but groups differed at PACU discharge, when the Dipyrone group mean score $(2.0 \pm 1.7)$ was higher than that of the Ketorolac group $(1.6 \pm 1.6)(p=0.04)$. All patients received morphine in the postoperative period and the total dose needed for pain control differed between groups ( $0.95 \mathrm{mg} \pm 1.55$ and $0.71 \mathrm{mg} \pm 1.21$ for the Dipyrone and the Ketorolac groups, respectively). Such difference, however, did not reach statistical significance $(p=0.34)$.

\section{DISCUSSION}

Hypovolemia in combination with high intraabdominal pressure may lead to restrictive flow to vital organs such as the kidney. During pneumoperitoneum at $12 \mathrm{mmHg}$, compressive effects on the renal parenchyma, renal vessels and inferior vena cava reduce effective renal plasma flow, GFR, sodium excretion and urine output $[19,20]$. In a porcine model, volume expansion with $15 \mathrm{ml} / \mathrm{kg} / \mathrm{h}$ isotonic solution could reverse the adverse effects of prolonged (4 hours) $\mathrm{CO}_{2}$ pneumoperitoneum $(15 \mathrm{mmHg})$ on renal blood flow and urine output [1]. When pneumoperitoneum is associated with NSAID administration and pre-existent kidney disease, acute renal failure may occur. Nevertheless, the use of NSAID can be safe in well hydrated patients without previous renal dysfunction [21], while in patients with normal preoperative renal function it may cause a transitory decrease of $16 \mathrm{ml} / \mathrm{min}$ in GFR in the early postoperative period [22]. The patients included in this study presented normal plasma creatinine and were submitted to $13 \mathrm{mmHg}$ pneumoperitoneum, but they were well hydrated during anesthesia.

GFR needs to be reduced $75 \%$ before serum creatinine reaches abnormal levels [23] and blood creatinine concentration is affected by other factors that do not depend upon renal function or injuries [24]. In this study, serum creatinine decreased in both groups in the postoperative period, probably due to hemodilution caused by intraoperative fluid loading and release of antidiuretic hormone, considered as a stress hormone that acts to maintain homeostasis [25-27]. According to the Cockcroft \& Gault formula [18], that estimates creatinine clearance, a postoperative GFR increase might have occurred in both groups as creatinine concentrations decreased. Did kidney function improve postoperatively in these patients? Albumin concentrations also decreased in both groups over the same period, and this speaks in favor of hemodilution in the postoperative period [28], holding it responsible for the decrease in creatinine and increase in its clearance. Since there was a positive correlation between the Cockcroft \& Gault method and the MDRD method, that also uses serum creatinine - and albumin - results, the GFR values obtained by both methods may be overestimated. Thus, no change in the concentration of the endogenous marker could be observed unless an important renal injury exceeding the dilution factor had occurred.

No significant difference was found between preoperative and postoperative cystatin $\mathrm{C}$ in both groups. If there had been hemodilution and no decrease in cystatin $C$ values, can one infer that these values would have indeed increased? Because cystatin $\mathrm{C}$ changes in these patients before creatinine over the postoperative period, would then a decrease in GFR have occurred? After filtration by the glomerulus, cystatin $\mathrm{C}$ is reabsorbed and catabolized (without secretion) by tubular epithelial cells, and only insignificant amounts are excreted in the urine [29]. As a consequence, although cystatin C is cleared by the kidneys, its urinary clearance is not routinely measured. Cystatin $\mathrm{C}$ would be a better marker of renal function than plasma creatinine $[30,31]$ - its production seems to be less variable between patients than that of creatinine. However, there is evidence that serum cystatin $\mathrm{C}$ levels are influenced by corticoid use, and by thyroid function. Cystatin C levels appear to be related to age, gender, weight, height, tobacco smoking status, and $\mathrm{C}$ reactive protein concentration $[32,33] . \Delta$ cystatin $\mathrm{C}$ (between pre and postoperative values of each group) showed no significant difference. However, it was greater in the group that received ketorolac. Further research is 
needed to find out whether this is clinically relevant.

In this study, the endogenous biomarkers of renal injury AP and $\gamma$-GT were dosed in urine. The increased secretion of both markers, that takes place before serum creatinine increases, indicates injury in the brush border membrane and loss of the microvilli structure. In rats submitted to an excessive dose of paracetamol (leading to acute proximal tubular injury), the urinary levels of these enzymes significantly increased in the first 24 hours, and returned to nearly baseline values after 48 - 72 hours, while GFR drastically decreased [34].

Our results show that urinary AP increased $24 \mathrm{~h}$ after surgery in both groups, indicating alteration in the tubular cells after surgery, apparently not related to ketorolac use. In the group that did not receive NSAID, AP values were higher at both time points studied. The concentration of $\gamma$-GT did not significantly change in the postoperative period in both groups, and in contrast with AP, it remained higher in the Ketorolac group. The product of both urinary enzymes showed a different profile in both groups and time points. In the Dipyrone group, the product was significantly higher preoperatively, but it decreased in the postoperative period. In patients receiving ketorolac, urinary enzyme product was significantly increased postoperatively. Whether such increase indicates some degree of injury at the brush border membrane of the tubular cell is not clear. Further studies are necessary to substantiate and better explain these results.

The difference in preoperative enzyme results observed between groups may be due to individual differences in creatinine excretion (the common denominator). This may be affected by various factors such as age, gender, race, body habits, obesity, chronic disease (poor nutrition, inflammation, lack of conditioning when bedridden, neuromuscular disease) and diet [35]. On the other hand, it is noteworthy that patients in the Ketorolac group at T1 had already received ketorolac at least 60 minutes earlier. The consequences of preoperative stress in this group would then be milder, hence less urinary enzyme released. The cross-talk mechanism involving the afferent and efferent arterioles and the renal tubules has been demonstrated. Such relation would be more intense than expressed by the anatomical contact between these structures, and has been known for a long time as the juxtaglomerular apparatus. Thus, decreased stress and stress hormones may indirectly influence the tubules by acting on these renal capillaries [36].

Ketorolac given as a pre-medication drug $(0.5 \mathrm{mg} / \mathrm{kg})$ in gynecological laparoscopy has been reported to influence the response of white blood cells, which is usually affected by surgical stress [37]. Administered intravenously, $15 \mathrm{mg}$ ketorolac followed by $7.5 \mathrm{mg} / \mathrm{h}$, in elective cesarean section, eased hemodynamic response to stress of tracheal intubation, improving the quality of analgesia and determining lower concentrations of plasma cortisol [38]. Ketorolac reaches maximum plasma concentration in 45 minutes and analgesic peak in one or two hours with an increased peak in aged patients with impaired renal function. In a study of 40 dogs submitted to hysterectomy and oophorectomy under general anesthesia, ketorolac was administered as one of the analgesics for treatment of postoperative pain $(0.5 \mathrm{mg} / \mathrm{kg})$. The analysis of serum creatinine and urea and renal function biomarkers such as $\gamma$-GT and AP showed that ketorolac is safe for this purpose [39].

In this study, good results were achieved using analgesia for pain control in both groups. According to VNS, only a small amount of rescue analgesia (morphine) was needed. Treatment with ketorolac as a premedication may ease renal response to preoperative stress. Additionally, low-dose ketorolac instillation into wounds has been demonstrated to modulate local inflammatory events, decrease postoperative pain, and reduce opioid consumption, suggesting that the administration of NSAIDs into surgical wounds may be an analgesic alternative to higher systemic dosing of NSAIDs [40].

In conclusion, both analgesia regimens used in this study that combined tramadol with either dipyrone or ketorolac, in well hydrated patients submitted to laparoscopic cholecystectomy, showed similar results in the PACU. Postoperatively, the effect on GFR might have been masked by hemodilution, but there was a discreet increase in the release of renal tubular enzymes when ketorolac was used, a response that requires further clarification.

\section{ACKNOWLEDGEMENTS}

Grant 07/51101-0_São Paulo Research Foundation (FAPESP); TP Medeiros was granted a scholarship from CAPES.

\section{REFERENCES}

[1] London, E.T., HO, H.S., Neuhaus, A.M., Wolfe, B.M., Rudich, S.M. and Perez, R.V. (2000) Effect of intravascular volume expansion on renal function during prolonged $\mathrm{CO}_{2}$ pneumoperitoneum. Annals of Surgery, 231, 195-201.

http://dx.doi.org/10.1097/00000658-200002000-00007

[2] Lindström, P., Wadström, J., Ollerstam, A., Johnsson, C. and Persson, A.E. (2003) Effects of increased intra-abdominal pressure and volume expansion on renal function in rat. Nephrology Dialysis Transplantation, 18, 22692277. http://dx.doi.org/10.1093/ndt/gfg362

[3] Demyttenaere, S., Feldman, L.S. and Fried, G.M. (2007) Effect of pneumoperitoneum on renal perfusion and function: A systematic review. Surgical Endoscopy, 21, 152160. http://dx.doi.org/10.1007/s00464-006-0250-x

[4] Michaloliakou, C., Chung, F. and Sharma, S. (1996) Preoperative multimodal analgesia facilitates recovery after 
ambulatory laparoscopic cholecistectomy. Anesthesia \& Analgesia, 82, 44-51.

[5] Burkle, H., Dunbar, S. and Van Aken, H. (1996) Remifentanil: A novel, short-acting $\mu$-opioid. Anesthesia \& Analgesia, 83, 646-651.

[6] Grond, S. and Sablotzki, A. (2004) Clinical pharmacology of tramadol. Clinical Pharmacokinetics, 43, 879-923. http://dx.doi.org/10.2165/00003088-200443130-00004

[7] Nagaoka, E., Minmi, K., Shiga, Y., Uezono, Y., Shiraishi, M., Aoyama, K. and Shigematsu, A. (2002) Tramadol has no effect on cortical renal blood flow despite increased serum catecholamine levels in anesthetized rats: Implications for analgesia in renal insufficiency. Anesthesia \& Analgesia, 94, 619-625.

http://dx.doi.org/10.1097/00000539-200203000-00026

[8] Koppert, W. and Scmelz, M. (2007) The impact of opioid-induced hyperalgesia for postoperative pain. Best Practice \& Research Clinical Anaesthesiology, 21, 65-83. http://dx.doi.org/10.1016/i.bpa.2006.12.004

[9] Kurumbail, R.G., Stevens, A.M., Gierse, J.K., McDonald, J.J., Stegeman, R.A., Pak, J.Y., Gildehaus, D., Miyashiro, J.M., Penning, T.D., Seibert, K., Isakson, P.C. and Stallings, W.C. (1996) Structural basis for selective inhibition of cuclooxygenase- 2 by anti-inflammatory agents. Nature, 384, 644-648. http://dx.doi.org/10.1038/384644a0

[10] Dunn, M.J. and Zambraski, E.J. (1980) Renal effects of drugs that inhibit prostaglandin synthesis. Kidney International, 18, 609-622.

http://dx.doi.org/10.1038/ki.1980.179

[11] De Souza Silva, M., Castiglia, Y.M., Vianna, P.T., Viero, R.M., Braz, J.R. and Cassetari, M.L. (2006) Rat model of depending prostaglandin renal state: Effect of ketoprofen. Renal Failure, 28, 77-84. http://dx.doi.org/10.1080/08860220500461294

[12] Coll, E., Botey, A., Alvarez, L., Poch, E., Quinto, L., Saurina, A., Vera, M., Piera, C. and Darnell, A. (2000) Serum cystatin $\mathrm{C}$ as a new marker for noninvasive estimation of glomerular filtration rate and as a marker for early renal impairment. American Journal of Kidney Diseases, 36, 29-34. http://dx.doi.org/10.1053/ajkd.2000.8237

[13] Knight, E.L., Verhave, J.C., Spiegelman, D., Hillege, H.L., Zeeuw, D.D., Curhan, G.C. and de Jong, P.E. (2004) Factors influencing serum cystatin $\mathrm{C}$ levels other than renal function and the impact on renal function measurement. Kidney International, 65, 1416-1421. http://dx.doi.org/10.1111/j.1523-1755.2004.00517.x

[14] Jung, K. and Burchardt, U. (1987) Urinary enzymes in research and in clinical medicine. Report on a symposium of the Humboldt-Universität Berlin and the Bezirkskrankenhaus Frankfurt/Oder in Frankfurt/Oder, 22-25 April 1987. Journal of Clinical Chemistry \& Clinical Biochemistry, 25, 823-828.

[15] Larsson, A., Malm, J., Grubb, A. and Hansson, L.O. (2004) Calculation of glomerular filtration rate expressed in $\mathrm{mL} / \mathrm{min}$ from plasma cystatin C values in $\mathrm{mg} / \mathrm{L}$. Scandinavian Journal of Clinical \& Laboratory Investigation, 64, 25-30. http://dx.doi.org/10.1080/00365510410003723

[16] Madero, M., Sarnak, M.J. and Stevens, L.A. (2006) Se- rum cystatin $\mathrm{C}$ as a marker of glomerular filtration rate. Current Opinion in Nephrology and Hypertension, 15, 610-616. http://dx.doi.org/10.1097/01.mnh.0000247505.71915.05

[17] Levey, A.S., Bosch, J.P., Lewis, J.B., Greene, T., Rogers, N. and Roth, D. (1999) A more accurate method to estimate glomerular filtration rate from serum creatinine: A new prediction equation. Annals of Internal Medicine, $\mathbf{3 0}$, 461-470.

http://dx.doi.org/10.7326/0003-4819-130-6-199903160-0 $\underline{0002}$

[18] Cockcroft, D.W. and Gault, M.H. (1976) Prediction of creatinine clearance from serum creatinine. Nephron, 16, 31-41. http://dx.doi.org/10.1159/000180580

[19] Ost, M.C., Tan, B.J. and Lee, B.R. (2005) Urological laparoscopy: Basic physiological considerations and immunological consequences. Journal of Urology, 174, 11831188 . http://dx.doi.org/10.1097/01.ju.0000173102.16381.08

[20] Miki, Y., Iwase, K., Kamiike, E., Taniguchi, E., Sakaguchi, K., Sumimura, J., Matsuda, H. and Nagai, I. (1997) Laparoscopic cholecystectomy and time-course changes in renal function. Surgical Endoscopy, 11, 838-841. http://dx.doi.org/10.1007/s004649900466

[21] Yuksel, H., Darcan, S., Kabasakal, C., Cura, A., Mir, S. and Mavi, E. (1998) Effect of enalapril on proteinuria, phosphaturia, and calciuria in insulin-dependent diabetes. Pediatric Nephrology, 12, 648-650. http://dx.doi.org/10.1007/s004670050520

[22] Lee, A., Cooper, M.G., Craig, J.C., Knight, J.F. and Keneally, J.P. (2007) Effects of nonsteroidal anti-inflammatory drugs on postoperative renal function in adults with normal renal function. Cochrane Database of Systematic Reviews, 2, CD002765.

[23] Kellen, M., Aronson, S., Roizen, M.F., Barnard, J. and Thisted, R.A. (1994) Predictive and diagnostic tests of renal failure: A review. Anesthesia \& Analgesia, 78, 134142. http://dx.doi.org/10.1213/00000539-199401000-00022

[24] Westhuyzen, J., Endre, Z.H., Reece, G., Reith, D.M., Saltissi, D. and Morgan, T.J. (2003) Measurement of tubular enzimuria facilitates early detection of acute renal impairment in the intensive care unit. Nephrology Dialysis Transplantation, 18, 543-551. http://dx.doi.org/10.1093/ndt/18.3.543

[25] Goldsmith, S.R. (1988) Baroreceptor-mediated suppression of osmotically stimulated vasopressin in normal humans. Journal of Applied Physics, 65, 1226-1230.

[26] Julier, K., Silva, R., Garcia, C., Bestmann, L., Frascarolo, P., Zollinger, A., Chassot, P.-G., Schmid, E.R., Turina, M.I., von Segesser, L.K., Pasch, T., Spahn, D.R. and Zaugg, M. (2003) Preconditioning by sevoflurane decreases biochemical markers for myocardial and renal dysfunction in coronary artery bypass graft surgery: A double-blinded, placebo-controlled, multicenter study. Anesthesiology, 98, 1315-1327.

http://dx.doi.org/10.1097/00000542-200306000-00004

[27] Youssef, M.A. and saleh Al-Mulhim, A. (2007) Effects of different anesthetic techniques on antidiuretic hormone 
secretion during laparoscopic cholecystectomy. Surgical Endoscopy, 21, 1543-1548. http://dx.doi.org/10.1007/s00464-006-9166-8

[28] Meyer, P., Pernet, P., Hejblum, G., Baudel, J.L., Maury, E., Offenstadt, G. and Guidet, B. (2008) Haemodilution induced by hydroxyethyl starches $130 / 0.4$ is similar in septic and non-septic patients. Acta Anaesthesiologica Scandinavica, 52, 229-235. http://dx.doi.org/10.1111/j.1399-6576.2007.01521.x

[29] Herget-Rosenthal, S., Feldkamp, T., Volbracht, L. and Kribben, A. (2004) Measurement of urinary cystatin C by particle-enhanced nephelometric immunoassay: Precision, interferences, stability, and reference range. Annals of Clinical Biochemistry, 41, 111-118. http://dx.doi.org/10.1258/000456304322879980

[30] Dharnidharka, V.R., Kwon, C. and Stevens, G. (2002) Serum cystatin $\mathrm{C}$ is superior to serum creatinine as a marker of kidney function: A meta-analysis. American Journal of Kidney Diseases, 40, 221-226. http://dx.doi.org/10.1053/ajkd.2002.34487

[31] Roos, J.F., Doust, J., Tett, S.E. and Kirkpatrick, C.M. (2007) Diagnostic accuracy of cystatin C compared to serum creatinine for the estimation of renal dysfunction in adults and children - A meta-analysis. Clinical Biochemistry, 40, 383-391.

http://dx.doi.org/10.1016/j.clinbiochem.2006.10.026

[32] Randers, E. and Erlandsen, E.J. (1999) Serum cystatin C as an endogenous marker of the renal function-A review. Clinical Chemistry and Laboratory Medicine, 37, 389395. http://dx.doi.org/10.1515/CCLM.1999.064

[33] Coll, E., Botey, A., Alvarez, L., Poch, E., Quinto, L., Saurina, A., Vera, M., Piera, C. and Darnell, A. (2000) Serum cystatin $\mathrm{C}$ as a new marker for noninvasive estimation of glomerular filtration rate and as a marker for early renal impairment. American Journal of Kidney Diseases, 36, 29-34. http://dx.doi.org/10.1053/ajkd.2000.8237

[34] Da Silva Melo, D.A., Saciura, V.C., Poloni, J.A., Oliveira,
C.S., Filho, J.C., Padilha, R.Z., Reichel, C.L., Neto, E.J., Oliveira, R.M., D'avila, L.C., Kessler, A. and de Oliveira, J.R. (2006) Evaluation of renal enzymuria and cellular excretion as an marker of acute nephrotoxicity due to an overdose of paracetamol in Wistar rats. Clinica Chimica Acta, 373, 88-91. http://dx.doi.org/10.1016/j.cca.2006.05.006

[35] Stevens, L.A., Coresh, J., Greene, T. and Levey, A.S. (2006) Medical progress: Assessing kidney functionMeasured and estimated glomerular filtration rate. New England Journal of Medicine, 354, 2473-2483. http://dx.doi.org/10.1056/NEJMra054415

[36] Ren, Y., Garvin, J.L., Liu, R. and Carretero, O.A. (2009) Cross-talk between arterioles and tubules in the kidney. Pediatric Nephrology, 24, 31-35. http://dx.doi.org/10.1007/s00467-008-0852-8

[37] Hong, J.Y. (2005) The effect of preoperative ketorolac on WBC response and pain in laparoscopic surgery for endometriosis. Yonsei Medical Journal, 46, 812-817. http://dx.doi.org/10.3349/ymj.2005.46.6.812

[38] El-Tahan, M.R., Warda, O.M., Yasseen, A.M., Attallah, M.M. and Matter, M.K. (2007) A randomized study of the effects of preoperative ketorolac on general anaesthesia for caesarean section. International Journal of Obstetric Anesthesia, 16, 214-220. http://dx.doi.org/10.1016/j.ijoa.2007.01.012

[39] Lobetti, R.G. and Joubert, K.E. (2000) Effect of administration of nonsteroidal anti-inflammatory drugs before surgery on renal function in clinically normal dogs. American Journal of Veterinary Research, 61, 1501-1507. http://dx.doi.org/10.2460/ajvr.2000.61.1501

[40] Carvalho, B., Lemmens, H.J., Ting, V. and Angst, M.S. (2013) Postoperative subcutaneous instillation of low-dose ketorolac but not hydromorphone reduces wound exudate concentrations of interleukin- 6 and interleukin-10 and improves analgesia following cesarean delivery. Journal of Pain, 14, 48-56.

http://dx.doi.org/10.1016/j.jpain.2012.10.002 